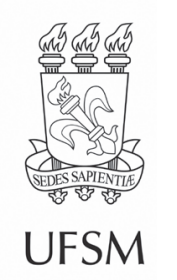

\title{
Artigos
}

\section{Use of different conditioning agents and quality evaluation of two lots of annatto (Bixa orellana) seeds}

\author{
Uso de diferentes condicionantes e avaliação da qualidade de dois lotes \\ de sementes urucum (Bixa orellana)
}

\author{
Alana Chocorosqui Fernandes ${ }^{\oplus}$ \\ Julio Cezar Tannure Faria" $\odot$ \\ José Marcio Rocha Faria" $\odot$ \\ Raquel Maria de Oliveira Pires" $\odot$ \\ Everson Reis Carvalho" $\odot$ \\ Heloisa Oliveira dos Santos" $" \odot$ \\ Instituto Federal do Acre, Xapuri, AC, Brazil \\ "Universidade Federal de Lavras, Lavras, MG, Brazil
}

\begin{abstract}
Due to the low germination of annatto seeds (Bixa orellana L.), it is necessary to test different techniques that facilitate and enable its production, such as the use of the physiological conditioning method. Here, we aimed to characterize the germination of two annatto seed lots under physiological conditioning. For this, two lots of seeds (newly-collected and stored) were submitted to physiological conditioning using an aerated solution of 1 ) deionized water; 2 ) cathodic water; 3 ) potassium nitrate $0.3 \%$; 4) sodium nitroprusside $100 \mu \mathrm{M}$; for $24 \mathrm{~h}$ and $48 \mathrm{~h}$, and an additional treatment (control) without conditioning. After the germination test, ungerminated seeds were submitted to a tetrazolium test at $0.075 \%$ at $30^{\circ} \mathrm{C}$, in the dark for $24 \mathrm{~h}$. We used a completely randomized factorial design $(4 \times 2+1)$ with four replications of 25 seeds per treatment. Despite the low germination already mentioned in the literature for this species, we obtained high germination without any type of dormancy-break pretreatment, even in lots stored for over 10 years with a water content of $8 \%$, characterizing this species as non-dormant. The germination and viability of Bixa orellana were influenced by seed water content decrease. The conditioning agents were not efficient to increase annatto seed germination. Further studies are needed to classify these seeds according to their storability.
\end{abstract}

Keywords: Cathodic water; Potassium nitrate; Sodium nitroprusside; Forest seed 


\section{RESUMO}

Devido à baixa germinação de sementes de Bixa orellana L., há a necessidade de se testar diferentes técnicas que viabilizem sua reprodução, como o condicionamento fisiológico. O objetivo do presente trabalho foi caracterizar a germinação de dois lotes de sementes de urucum sob efeito do condicionamento fisiológico. Para isso, sementes de dois lotes (recém-colhido e armazenado) foram submetidas ao condicionamento fisiológico em solução aerada de: 1) água deionizada; 2) água catódica; 3) nitrato de potássio a 0,3\%; 4) nitroprussiato de sódio a $100 \mu \mathrm{M}$; por 24 e 48h, e um tratamento adicional (controle) sem condicionamento. Após o teste de germinação, as sementes que não germinaram foram submetidas ao teste de tetrazólio a $0,075 \%$ a $30{ }^{\circ} \mathrm{C}$, no escuro, durante $24 \mathrm{~h}$. O delineamento experimental utilizado foi o inteiramente casualizado, em esquema fatorial $(4 \times 2+1)$ com quatro repetições de 25 sementes por tratamento. Apesar da baixa germinação já relatada para a espécie, foi possível obter germinação sem nenhum tipo de pré-tratamento como quebra de dormência, mesmo em lote armazenado por 10 anos e com teor de água de 8\%. Os agentes condicionantes não foram eficientes no aumento da germinação de sementes de urucum. São necessários novos trabalhos para classificação da espécie quanto ao seu armazenamento.

Palavras-chave: Água catódica; Nitrato de potássio; Nitroprussiato de sódio; Semente florestal

\section{INTRODUCTION}

Bixa orellana L. (Bixaceae), commonly known as annatto, is a tree or shrub nonendemic from Brazil. It is used for food, medicinal and ornamental purposes (VILAR et al., 2014). One of the most widely used colorants in the world is extracted from its seeds and applied in the textile, paint, cosmetic, pharmaceutical, and food industries (JOSEPH et al., 2010; POORNIMA; AMBIKA, 2012; VILAR et al., 2014).

Its toughness, fast growth, and capacity for natural development in soils with low to medium fertility, render this species useful to recover degraded areas (SOUZA et al., 2016).

The propagation of Bixa orellana is performed mainly via sexual reproduction. This hampers its production because seeds usually present low germination and uniformity (LOPES et al., 2008; JOSEPH et al., 2010; GOMES, et al., 2016; DAS et al., 2018). Some authors attribute these low results to seed physical dormancy (YOGEESHA et al., 2005; CASTELLO et al., 2012; POORNIMA; AMBIKA, 2012; DAS et al., 2018; COSTA et al., 2018). 
As a physiological attribute of seed quality, rapid and uniform germination leads to higher and better seedling production. Among different cultures, one of the most widely used techniques to achieve this is the preconditioning method (SANTOS et al., 2008). This technique consists in pre-soaking the seeds, allowing the occurrence of the initial phases of the germination process (phases I and II) along with their respective biochemical events, but preventing root protrusion, which marks the transition between phases II and III (BEWLEY et al., 2013). Later, when sown, the seeds show an increase in the germination and uniformity rates.

Many osmotic agents are used for seed physiological conditioning, such as sodium chloride $(\mathrm{NaCl})$, potassium nitrate $\left(\mathrm{KNO}_{3}\right)$, magnesium sulfate $(\mathrm{MgSO} 4)$, magnesium chloride $(\mathrm{MgCl} 2)$, manganese sulphate (MnSO4), polyethylene glycol (PEG), and mannitol (MARCOS-FILHO, 2015). According to Marcos-Filho (2015), any concentration of solute that allows the soaking process but prevents root protrusion can be used for conditioning, including water, hormones, growth regulators, and acids (CASTELLO et al., 2012; DAS et al., 2018).

One alternative that has been studied to minimize the stress caused by drying on seeds is cathodic protection. Studies have shown that the use of cathodic water reduces the action of free radicals by working as an electron source and reacting with these radicals, which leads to a reduction in oxidative damages (BERJAK et al., 2011).

Although Bixa orellana seeds have germination issues, it is important to test methodologies that may increase their germination. Thus, here we aimed to characterize the germination of two annatto seed lots under the effects of physiological conditioning. 


\section{MATERIAL AND METHODS}

\subsection{Seed obtention}

Bixa orellana L. fruits were collected in the region of Lavras-MG in 2008 and 2019. The seeds were manually removed from the fruits, dried until hygroscopic equilibrium, and stored in a dry cold chamber $\left( \pm 10^{\circ} \mathrm{C}\right.$ and $40 \%$ UR) until the beginning of the experiments. Initially, we determined the water content and the physiological quality of the lots through the germination test, germination speed index (GSI), and first count of germination ( $F C$ ). In the final count of the germination test, the remaining seeds were submitted to the tetrazolium evaluation test.

The experiment was conducted with two different lots that differed in storage period: lot 1 (harvested in 2019) named newly-collected and lot 2 (harvested in 2008), named stored.

\subsection{Physiological conditioning}

As conditioning agents, we used; 1) deionized water; 2) cathodic water; 3) potassium nitrate $\left.0.3 \%\left(\mathrm{KNO}_{3}\right) ; 4\right)$ sodium nitroprusside $100 \mu \mathrm{M}$ and an additional treatment (control) without conditioning. The seeds were conditioned in Erlenmeyer flasks containing $250 \mathrm{~mL}$ of each different agent. The treatments were kept in BOD at $25^{\circ} \mathrm{C}$ in the dark by 24 and $48 \mathrm{~h}$. Aeration was done by air compressors.

The cathodic water was prepared according to the methodology described by Berjak et al. (2011), with some alterations, being: $1 \mathrm{~L}$ of solution with electrolytes, $0.5 \mu \mathrm{L}$ of $\mathrm{CaCl} 2.2 \mathrm{H} 2 \mathrm{O}$ and $500 \mu \mathrm{L}$ of $\mathrm{MgCl} 2.6 \mathrm{H} 2 \mathrm{O}$, conditioned in a horizontal compartment, specific to the electrophoretic run. We used an agar salt-bridge with potassium chloride (3 g/L). To this electrolyzed solution, we applied an electric potential difference of 60 Volts for 60 minutes, at room temperature. This produced $500 \mathrm{~mL}$ of anodic water (oxidized) with a pH close to 3 , and $500 \mathrm{~mL}$ of cathodic water (reduced) with a pH close to 12 , which was used in this experiment. 
After each conditioning period, the seeds were removed from the solutions, washed in running water and submitted to asepsis with sodium hypochlorite at $2.5 \%$ for 10 minutes. Then, they were washed with distilled water three consecutive times and submitted to physiological evaluations.

\subsection{Determination of seed water content}

Seed water content was determined through the oven method at $105^{\circ} \mathrm{C}$ for 24 h (BRAZIL, 2009). After this period, seed dry weight was obtained. The results were expressed in average moisture content (wet basis).

\subsection{Physiological analyses}

The germination test was performed in gerbox chambers with four replications of 25 seeds for each treatment. Seeds were sown on moistened germitest paper in the proportion of $2.5 \mathrm{~mL}$ of water per $\mathrm{g}$ of paper and kept in B.O.D. (Biological Oxygen Demand), regulated at $25^{\circ} \mathrm{C}$ and constant light. The number of germinated seeds was counted daily to calculate the germination speed index (GSI) (MAGUIRE, 1962). The results from the germination test were expressed in normal seedling percentages.

The seeds that did not germinate until the last day of testing were cut in half and submitted to the tetrazolium test for viability evaluation, as proposed by Delouche and Baskin (1973), adapted by AOSA (1983) and suggested by Brazil (2009). For this, seeds were soaked in a solution of $2,3,5$ triphenyltetrazolium chloride, $0.075 \%$ at $30^{\circ} \mathrm{C}$, in the dark for $24 \mathrm{~h}$, according to the methodology used by Picolotto et al. (2013) for annatto seed. We analyzed embryo viability with the aid of a magnifying glass (10x of amplification) for better visualization, classifying the seeds between viable and nonviable. 


\subsection{Experimental design}

We used a completely randomized design (DIC) with four replications of 25 seeds per treatment in a factorial scheme $(4 \times 2+1)$ : four conditioning treatments (deionized water, cathodic water, potassium nitrate, and sodium nitroprusside), two immersion periods (24 and $48 \mathrm{~h}$ ) and an additional treatment (control) without conditioning. This resulted in a total of 9 treatments per lot. Data normality was verified through a ShapiroWilk test. The results were submitted to analysis of variance and the means were compared using the Tukey test at 5\% probability. Statistical analyses were performed using the statistical program R (R CORE TEAM, 2019).

\section{RESULTS AND DISCUSSION}

Despite reports from the literature about the low germination of Bixa orellana seeds (AMARAL et al., 2000; JOSEPH et al., 2010; DAS et al., 2018), in the additional treatment without any conditioning agent, the averages of germination and germination speed index for the newly-collected lot (Lot 1), were $78 \%$ and 2.84 , respectively. The same treatment, applied to the stored lot (Lot 2), resulted in averages of germination and germination speed index of $36 \%$ and 0.76 respectively (Table 1). The water content was $13 \%$ and $8 \%$ for lots 1 and 2, respectively.

Many authors have attributed the low germination of annatto seeds to seed coat impermeability (CASTELLO et al., 2012; COSTA et al., 2018; PEREIRA et al., 2012; POORNIMA; AMBIKA, 2012). In anatomical analyses of annatto seeds, Amaral et al. (2000) observed the formation of structures that hardened the seed coat when seed water content varied between $26.4 \%$ and $10.4 \%$, leading to seed impermeability and a decrease in germination ( $40 \%$ and $20 \%$, respectively). Despite these observations, the germination values that we obtained in this study did not involve dormancy-break treatments. 
Fernandes, A. C.; Faria, J. C. T.; Faria, J. M. R.; Pires, R. M. O.; Carvalho, E. R.; Santos, H. O. | 814

Yogeesha et al. (2005), exploring the influence of seed maturity, suggested that the critical moisture content for annatto germination is between $22-28 \%$. The authors also observed the formation of tough seed coats at a water content below $12 \%$. They also observed that the germination percentage decreased in $96.3,95,64$, and $12 \%$ at a water content of $61,28.6,21.6$, and $6 \%$, respectively. The maximum dry matter accumulation was achieved at a water content of 61\%. Poornima and Ambika (2012) also reported annatto seed toughness after seed desiccation to a water content lower than $10 \%$. In this work, even with a water content at or below $13 \%$, germination was higher than $35 \%$.

Table 1 - Averages of the percentage of germination, germination speed index and first count of germination of Bixa orellana L. seeds submitted to different physiological conditioning treatments for $24 \mathrm{~h}$ and $48 \mathrm{~h}$

\begin{tabular}{|c|c|c|c|c|c|c|}
\hline \multirow{2}{*}{ Physiological conditioning } & \multicolumn{2}{|c|}{ Germination (\%) } & \multicolumn{2}{|c|}{ GSI } & \multicolumn{2}{|c|}{ FC (\%) } \\
\hline & $24 \mathrm{~h}$ & $48 \mathrm{~h}$ & $24 \mathrm{~h}$ & $48 \mathrm{~h}$ & $24 \mathrm{~h}$ & $48 \mathrm{~h}$ \\
\hline \multicolumn{7}{|c|}{ Lot 1} \\
\hline Deionized water & $70 \mathrm{aA}^{*}$ & $64 \mathrm{aB}^{*}$ & $3.90 \mathrm{aA}^{*}$ & $4.02 \mathrm{aA}^{*}$ & $49 \mathrm{aA}$ & $49 \mathrm{aA}$ \\
\hline Cathodic water & $74 \mathrm{aA}^{*}$ & $68 \mathrm{aB}^{*}$ & $4.10 \mathrm{aA}^{*}$ & $4.06 \mathrm{aA}^{*}$ & $49 \mathrm{aA}$ & $51 \mathrm{aA}$ \\
\hline $\mathrm{KNO}_{3}$ & $73 a A^{*}$ & $59 \mathrm{aB}^{*}$ & $4.11 \mathrm{aA}^{*}$ & $3.29 \mathrm{abA}^{*}$ & $56 \mathrm{aA}$ & $43 \mathrm{aA}$ \\
\hline SNP & $65 \mathrm{aA}^{*}$ & $63 \mathrm{aB}^{*}$ & $3.06 b A^{*}$ & $2.71 \mathrm{bA}^{*}$ & $40 \mathrm{aA}$ & 39 aA \\
\hline Treat. Additional & \multicolumn{2}{|c|}{78} & \multicolumn{2}{|c|}{2.84} & \multicolumn{2}{|c|}{42} \\
\hline \multicolumn{7}{|c|}{ Lot 2} \\
\hline Deionized water & $34 \mathrm{aA}$ & $31 \mathrm{aA}$ & $0.77 \mathrm{aA}$ & $0.68 \mathrm{aA}$ & $8 \mathrm{aA}$ & $5 \mathrm{aA}$ \\
\hline Cathodic water & $40 \mathrm{aA}$ & $34 \mathrm{aA}$ & $0.69 \mathrm{aA}$ & $0.63 \mathrm{aA}$ & $3 a A$ & $4 \mathrm{aA}$ \\
\hline $\mathrm{KNO}_{3}$ & $36 \mathrm{aA}$ & $40 \mathrm{aA}$ & $0.77 \mathrm{aA}$ & $0.74 \mathrm{aA}$ & $7 \mathrm{aA}$ & $4 \mathrm{aA}$ \\
\hline SNP & 36 aA & $33 \mathrm{aA}$ & $0.82 \mathrm{aA}$ & $0.69 \mathrm{aA}$ & $7 \mathrm{aA}$ & $5 \mathrm{aA}$ \\
\hline Treat. Additional & \multicolumn{2}{|c|}{36} & \multicolumn{2}{|c|}{0.76} & \multicolumn{2}{|c|}{6} \\
\hline
\end{tabular}

Source: Authors (2020)

In where: GSI: germination speed index; FC: first count of germination; $\mathrm{KNO}_{3}$ : potassium nitrate; SNP: sodium nitroprusside. 1 Means followed by the same uppercase letter in each column and the same lowercase letter in each line, for each parameter, indicate non-significant differences by the Tukey test $(p>0.05)$. * Statistically different from the additional treatment by the same test. 
Seeds with high water content tend to lose viability more easily due to the decrease in the hydration tissues essential to start the germination process (BASKIN; BASKIN, 2014). Orthodox seeds, however, are dispersed with a low water content, which can be as low as 7\%. A low metabolism promotes higher seed longevity (WYSE; DICKIE, 2017).

This reduction in water content after physiological maturity is a natural process in orthodox seeds and occurs after the seeds leave the mother plant and, consequently, dehydrate. At this moment, the seeds undergo a series of internal adjustments that prepare them for germination, which include enzyme synthesis, organization of the membrane system, and intense metabolic activities (MARCOS-FILHO, 2015).

The cumulative germination results showed that, on average, seeds from the newly-collected lot (Lot 1) submitted to the additional treatment began to germinate on the fourth day after soaking; whereas the seeds that underwent physiological conditioning germinated on the second day. This revealed the soaking of the seeds, although this is uncommon among dormant seeds not submitted to dormancybreaking treatments.

Dormancy is a phenomenon that manifests in the seeds of some species and prevents the germination of even viable seeds under suitable environmental conditions (MARCOS-FILHO, 2015).

On average, the lot 2 seeds submitted to the additional treatment began to germinate on the sixth day after the beginning of soaking, whereas the seeds submitted to physiological conditioning germinated on the fifth day (Figure 2). The longer time before germination of the lot 2 seeds is possibly related to the rate of deterioration of stored seeds. 
Figure 1 - Cumulative germination of Bixa orellana seeds submitted to different conditioning treatments in comparison with the control treatment. Newly-collected lot (Lot 1). A - Conditioning in deionized water (AD) for 24 hours. B - Conditioning in deionized water (AD) for 48 hours. C - Conditioning in cathodic water (AC) for 24 hours. D - Conditioning in cathodic water (AC) for 48 hours. E - Conditioning in potassium nitrate $\left(\mathrm{KNO}_{3}\right)$ for 24 hours. $\mathrm{F}$ - Conditioning in potassium nitrate $\left(\mathrm{KNO}_{3}\right)$ for 48 hours. $\mathrm{G}$ - Conditioning in sodium nitroprusside (SNP) for 24 hours. $\mathrm{H}$ - Conditioning in sodium nitroprusside (SNP) for 48 hours

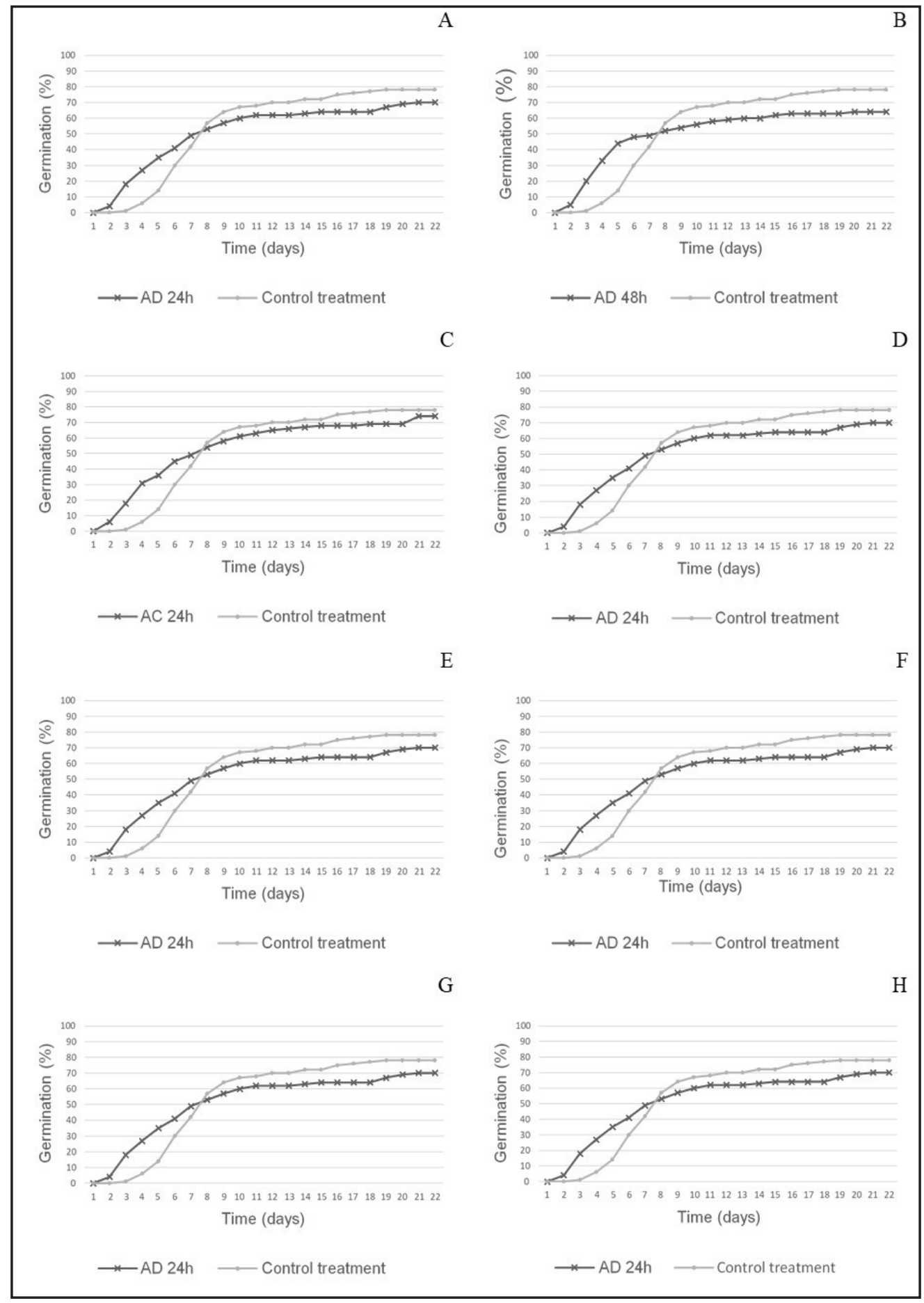

Source: Authors (2020) 
Figure 2 - Cumulative germination of Bixa orellana seeds submitted to different conditioning treatments in comparison with the control treatment. Stored lot (Lot 2). A - Conditioning in deionized water (AD) for 24 hours. B - Conditioning in deionized water (AD) for 48 hours. $C$ - Conditioning in cathodic water (AC) for 24 hours. D - Conditioning in cathodic water (AC) for 48 hours. E - Conditioning in potassium nitrate $\left(\mathrm{KNO}_{3}\right)$ for 24 hours. $\mathrm{F}$ - Conditioning in potassium nitrate $\left(\mathrm{KNO}_{3}\right)$ for 48 hours. G - Conditioning in sodium nitroprusside (SNP) for 24 hours. $\mathrm{H}$ - Conditioning in sodium nitroprusside (SNP) for 48 hours

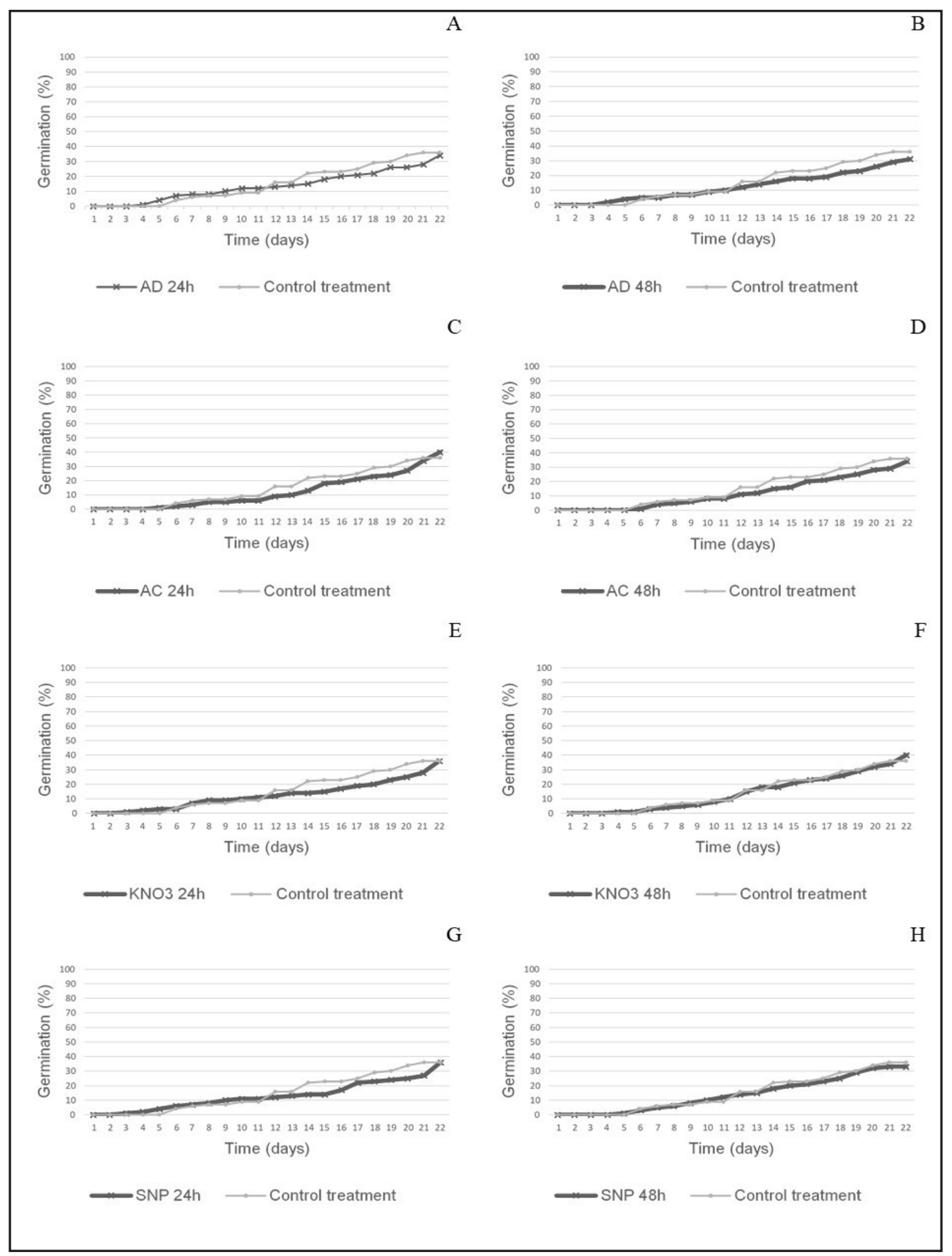

Source: Authors (2020) 
To verify the influence of water content on the germination process, seeds from lot 1 (newly-collected), with water content close to 56\% underwent an additional germination test. The average germination of this lot was 99\%, showing that water content can influence seed germination in Bixa orellana. Joseph et al. (2011) also observed a high germination percentage (93.3\%) in annatto seeds with high water content.

As shown in Table 1, there was no statistical difference between the seeds from lots 1 and 2 in response to the different conditioning treatments. However, among the lot 1 seeds, we found significant differences in the effects of the conditioning periods, with higher responses in the $24 \mathrm{~h}$ treatment compared with the $48 \mathrm{~h}$ treatment.

Among the lot 1 seeds, the additional treatment resulted in higher germination thanthephysiological conditioning treatments. Among the lot2 seeds, both theadditional treatment and the physiological conditioning treatments resulted in statistically equal germination results, suggesting that the agents used were not efficient to increase the germination of stored annatto seeds. The maximum germination rate observed in studies that tested different conditioning treatments was 35.9\%, using a mixture of PEG 6000 and $\mathrm{KNO}_{3}$ solutions for $24 \mathrm{~h}$ at $10^{\circ} \mathrm{C}$ (KISSMANN et al., 2013). These authors also associated the low germination results with seed coat toughness, recommending the combination of studies that also investigate seed dormancy, aiming to improve the reproduction of this species (AMARAL et al., 2000; CASTELLO et al., 2012)

The use of SNP and $\mathrm{KNO}_{3}$ for 24 hours in a concentration of $100 \mu \mathrm{M}$ was efficient in increasing the GSI rates in Plathymenia reticulata by preserving membrane integrity and stimulating superoxide dismutase enzyme activity (PEREIRA et al., 2010). In Dalbergia nigra seeds, the use of SNP and $\mathrm{KNO}_{3}$ stimulated the germination process and increased germination speed index, with the best results attained at the concentrations of 10 and $100 \mu \mathrm{M}$ after $24 \mathrm{~h}$ and 48h of soaking (ATAÍDE et al., 2015). Even with similar treatments, the use of these conditionings agents in our study was not enough to improve annatto seed germination in the two lots and GSI in lot 2. 
Evaluating the germination and the vigor of annatto seeds under different concentrations of a plant biostimulant, Araujo Neto et al. (2018) observed an increase of $40 \%$ in the germination of seeds soaked for 4 and 8 hours compared with those without any previous soaking. The authors suggested that the treatment was efficient to break annatto seed dormancy. The germination varied between 12 and 18\%, rates still lower than those described in this paper, even without the conditioning process (ARAUJO NETO et al., 2018).

Although the annatto seeds showed good GSI results with the use of cathodic water, these were statistically equal to using deionized water and $\mathrm{KNO}_{3}$ in lot 1, and to all other treatments in lot 2. We, therefore, did not find a significant influence of these agents in annatto seed germination. Although the use of cathodic water has been promising to increase responses to stress during procedures such as cryopreservation and for showing antioxidant effects (BERJAK et al., 2011), no evidence of improvement on annatto seed germination was observed here.

After physiological conditioning, it is common to observe an acceleration in germination speed (PEREIRA et al., 2010; ATAÍDE et al., 2015). Here, this was verified in lot 1 , but not in lot 2 (Figure 1).

The percentage of normal and abnormal seedlings did not differ among the treatments. As for seed mortality, in lots 1 and 2, the percentage of dead seeds was statistically higher among conditioned seeds compared with the additional treatment. In the stored lot (lot 2), physiological conditioning for 48 hours also increased seed mortality (Tables 2 and 3). Fungal contamination was unavoidable among the annatto seeds and the main cause of the high occurrence of abnormal seedlings (Table 3). 
Table 2 - Summary of the analysis of variance from the data related to germination, first count of germination, abnormal seedlings, dead seeds, tough seeds, and germination speed index of Bixa orellana L. seeds submitted to different physiological conditioning treatments

\begin{tabular}{|c|c|c|c|c|c|c|c|}
\hline \multirow{2}{*}{ V.S. } & \multirow{2}{*}{ D. F. } & \multicolumn{6}{|c|}{ Mean Square } \\
\hline & & G & FC & AS & DS & TS & GSI \\
\hline \multicolumn{8}{|c|}{ Lote 1} \\
\hline Cond. & 3 & 69.33 & 201.33 & 281.83 & 40.50 & 64.50 & $2.3139 *$ \\
\hline Period. & 1 & $392 *$ & 72 & 0.50 & 144.50 & 180.50 & 0.5832 \\
\hline Cond.*Period & 3 & 50.67 & 92 & 53.83 & 39.17 & 41.83 & 0.3405 \\
\hline Error & 24 & 91.33 & 95 & 130.17 & 40.83 & 47.50 & 0.4589 \\
\hline Total & & 2944 & 3232 & 4131.50 & 1363.50 & 1639.50 & 19.56 \\
\hline CV (\%) & & 14.26 & 20.74 & 46.33 & 36.78 & 52.51 & 18.53 \\
\hline \multicolumn{8}{|c|}{ Lote 2} \\
\hline Cond. & 3 & 49.33 & 13.83 & 29.83 & 33.33 & 136.17 & 0.0152 \\
\hline Period & 1 & 32.00 & 24.50 & 24.50 & $882.00 *$ & $684.50 *$ & 0.0504 \\
\hline Cond.*Period & 3 & 36.00 & 7.17 & 15.17 & 110.00 & 23.17 & 0.003 \\
\hline Error & 24 & 75.67 & 15.83 & 15.50 & 47.67 & 60.50 & 0.035 \\
\hline Total & & 2104 & 467.50 & 435.50 & 2456 & 2611.50 & 0.9396 \\
\hline CV (\%) & & 24.50 & 74.03 & 129.19 & 29.38 & 23.31 & 25.66 \\
\hline
\end{tabular}

Source: Authors (2020)

In where: G: germination; FC: first count of germination; AS: abnormal seedlings, DS: dead seeds, TS: tough seeds; GSI: germination speed index; VS: variation source; DF: degree of freedom; Cond.: physiological conditioning; Period: period of conditioning; CV: coefficient of variation. (*) Significant values obtained by the $\mathrm{F}$ test at $5 \%$. 
To optimize physiological conditioning, favorable and standardized conditions for germination are needed. But seed response may also vary according to genotype, seed vigor, seed lot quality, seed size, temperature, water absorption speed, aeration, and type of conditioning (MARCOS-FILHO, 2015).

Despite the water availability provided by soaking and aeration, many seeds displayed tough seed coats. A higher percentage of tough seeds was observed in the stored lot (lot 2) when seeds were conditioned for $24 \mathrm{~h}$. The additional treatment showed a higher percentage of tough seeds compared with the conditioning treatments (Table 3). This was expected given that this treatment did not involve seed soaking.

Table 3 - Comparison between the additional treatment and the physiological conditioning treatments for the percentage of normal seedlings, abnormal seedlings, dead seeds, tough seeds, and percentage of dormant seeds of Bixa orellana L.

\begin{tabular}{|c|c|c|c|c|c|c|c|c|c|c|}
\hline \multirow{2}{*}{$\begin{array}{l}\text { Physiological } \\
\text { conditioning }\end{array}$} & \multicolumn{2}{|c|}{ SN (\%) } & \multicolumn{2}{|c|}{ AS (\%) } & \multicolumn{2}{|c|}{ DS (\%) } & \multicolumn{2}{|c|}{ TS (\%) } & \multicolumn{2}{|c|}{ DormS (\%) } \\
\hline & $24 \mathrm{~h}$ & $48 \mathrm{~h}$ & $24 \mathrm{~h}$ & $48 \mathrm{~h}$ & $24 \mathrm{~h}$ & $48 \mathrm{~h}$ & $24 \mathrm{~h}$ & $48 \mathrm{~h}$ & $24 \mathrm{~h}$ & $48 \mathrm{~h}$ \\
\hline \multicolumn{11}{|c|}{ Lot 1} \\
\hline Deionized water & $40 \mathrm{aA}$ & $27 \mathrm{aA}$ & $30 \mathrm{aA}$ & $37 \mathrm{aA}$ & $16 \mathrm{aA}^{*}$ & $25 \mathrm{aA}^{*}$ & $10 \mathrm{aA}$ & $10 \mathrm{aA}$ & $3 \mathrm{aA}$ & $1 \mathrm{aA}$ \\
\hline Cathodic water & $51 \mathrm{aA}$ & $49 \mathrm{aA}$ & $23 \mathrm{aA}$ & $19 \mathrm{aA}$ & $16 \mathrm{aA}^{*}$ & $16 \mathrm{aA}^{*}$ & $8 \mathrm{aA}$ & $15 \mathrm{aA}$ & $2 \mathrm{aA}$ & $1 \mathrm{aA}$ \\
\hline $\mathrm{KNO}_{3}$ & $51 \mathrm{aA}$ & $37 \mathrm{aA}$ & $22 \mathrm{aA}$ & $22 \mathrm{aA}$ & $12 \mathrm{aA}^{*}$ & $19 \mathrm{aA}^{*}$ & $10 \mathrm{aA}$ & $20 \mathrm{aA}$ & $5 \mathrm{aA}$ & $2 \mathrm{aA}$ \\
\hline SNP & $41 \mathrm{aA}$ & $43 a A$ & $24 \mathrm{aA}$ & $20 \mathrm{aA}$ & $17 \mathrm{aA}^{*}$ & $18 \mathrm{aA}^{*}$ & $15 \mathrm{aA}$ & $17 \mathrm{aA}$ & $3 \mathrm{aA}$ & $2 \mathrm{aA}$ \\
\hline Treat. Additional & \multicolumn{2}{|c|}{41} & \multicolumn{2}{|c|}{37} & \multicolumn{2}{|c|}{4} & \multicolumn{2}{|c|}{16} & \multicolumn{2}{|c|}{2} \\
\hline \multicolumn{11}{|c|}{ Lot 2} \\
\hline Deionized water & $31 \mathrm{aA}$ & $31 \mathrm{aA}$ & $3 \mathrm{aA}$ & $2 \mathrm{aA}$ & $16 \mathrm{aA}^{*}$ & $28 \mathrm{aB}^{*}$ & $44 \mathrm{aB}^{*}$ & $30 \mathrm{aA}^{*}$ & $6 \mathrm{aA}$ & $11 \mathrm{aA}$ \\
\hline Cathodic water & $40 \mathrm{aA}$ & $34 \mathrm{aA}$ & $0 \mathrm{aA}$ & $0 \mathrm{aA}$ & $16 \mathrm{aA}^{*}$ & $35 \mathrm{aB}^{*}$ & $32 \mathrm{aB}^{*}$ & $23 a A^{*}$ & $12 \mathrm{aA}$ & $8 \mathrm{aA}$ \\
\hline $\mathrm{KNO}_{3}$ & $34 \mathrm{aA}$ & $40 \mathrm{aA}$ & $2 \mathrm{aA}$ & $5 \mathrm{aA}$ & $21 \mathrm{aA}^{*}$ & $22 \mathrm{aB}^{*}$ & $38 \mathrm{aB}^{*}$ & $30 \mathrm{aA}^{*}$ & $5 \mathrm{aA}$ & $8 \mathrm{aA}$ \\
\hline SNP & $34 \mathrm{aA}$ & $33 a A$ & $2 \mathrm{aA}$ & $7 \mathrm{aA}$ & $20 \mathrm{aA}^{*}$ & $30 \mathrm{aB}^{*}$ & $38 \mathrm{aB}^{*}$ & $32 \mathrm{aA}^{*}$ & $6 \mathrm{aA}$ & $5 \mathrm{aA}$ \\
\hline Treat. Additional & \multicolumn{2}{|c|}{36} & \multicolumn{2}{|c|}{0} & \multicolumn{2}{|c|}{7} & \multicolumn{2}{|c|}{47} & \multicolumn{2}{|c|}{10} \\
\hline
\end{tabular}

Source: Authors (2020)

On what: NS: normal seedlings; AS: abnormal seedlings; DS: dead seeds; TS: tough seeds; DormS: dormant seeds; $\mathrm{KNO}_{3}$ : potassium nitrate; SNP: sodium nitroprusside. 1 Means followed by the same uppercase letter in each column and the same lowercase letter in each line, for each parameter, indicate non-significant differences by the Tukey test ( $p>0.05)$. * Statistically different from the additional treatment by the same test. 
The conditions during seed physiological conditioning also contribute to the growth of fungi and bacteria, causing seed mortality as seen here. Even with the use of sodium hypochlorite at $2.5 \%$ for 10 minutes, the occurrence of abnormal seedlings was related to fungal growth in the germination paper. The use of microbe-free seeds is difficult, especially in forest seeds, because pathogens can be transported within the seed tissue (CARMO et al., 2017). Ferreira and Novembre (2015) also reported high fungal contamination in germination tests of annatto seeds under high humidity conditions. Other studies have shown evidence that mercuric chloride, directly applied to seeds, is efficient to increase the germination of annatto seeds (JOSEPH et al., 2010).

To verify the viability of tough seeds that remained from the germination test, we performed the tetrazolium test. Newly-collected seeds (lot 1) showed a low number of dormant seeds, with $81 \%$ of these being classified as inviable. Among the tough remaining seeds, $80 \%$ were classified as inviable (Figure 3). Lot 2, however, showed a large number of tough seeds, among which $75 \%$ were considered inviable. Among the dormant seeds, $87 \%$ were classified as inviable (Figure 4).

Even though dormancy had been previously reported among annatto seeds (JOSEPH et al., 2010; CASTELLO et al., 2012; POORNIMA; AMBIKA, 2012; PICOLOTTO et al., 2013; FERREIRA; NOVEMBRE, 2015; GOMES et al., 2016), we observed the soaking of seeds submitted to physiological conditioning, even without pretreatment.

Comparing these results with those from the stored lot (lot 2), the seeds germinated without a pretreatment even after 10 years of storage.

These results are helpful to classify annatto seeds correctly, according to their storage behavior. Our observations on the behavior of annatto seeds after storage conflict with those from the literature. Many authors classify these seeds as showing an intermediate behavior because they tolerate desiccation to as low as $10 \%$ of water content, but viability and longevity decrease around $5 \%$ of water content (GOLDBACH, 1979). 
Annatto seeds had been previously classified as non-tolerant to desiccation (PEREIRA et al.,2012; POORNIMA; AMBIKA, 2012) because research had shown that seed toughness manifested after drying them below $10 \%$ of water content (AMARAL et al., 2000; POORNIMA; AMBIKA, 2012). However, we are not aware of studies that have evaluated long storage periods for this species.

Figure 3 - Results from the tetrazolium test for tough (A) and dormant seeds (B) from the newly-collected lot (Lot 1) that remained after the germination test: conditioned in deionized water (AD) for 24 and 48h, conditioned in cathodic water (AC) for 24 and 48h, conditioned in potassium nitrate $\left(\mathrm{KNO}_{3}\right)$ for 24 and $48 \mathrm{~h}$ and conditioned in sodium nitroprusside (SNP) for 24 and $48 \mathrm{~h}$
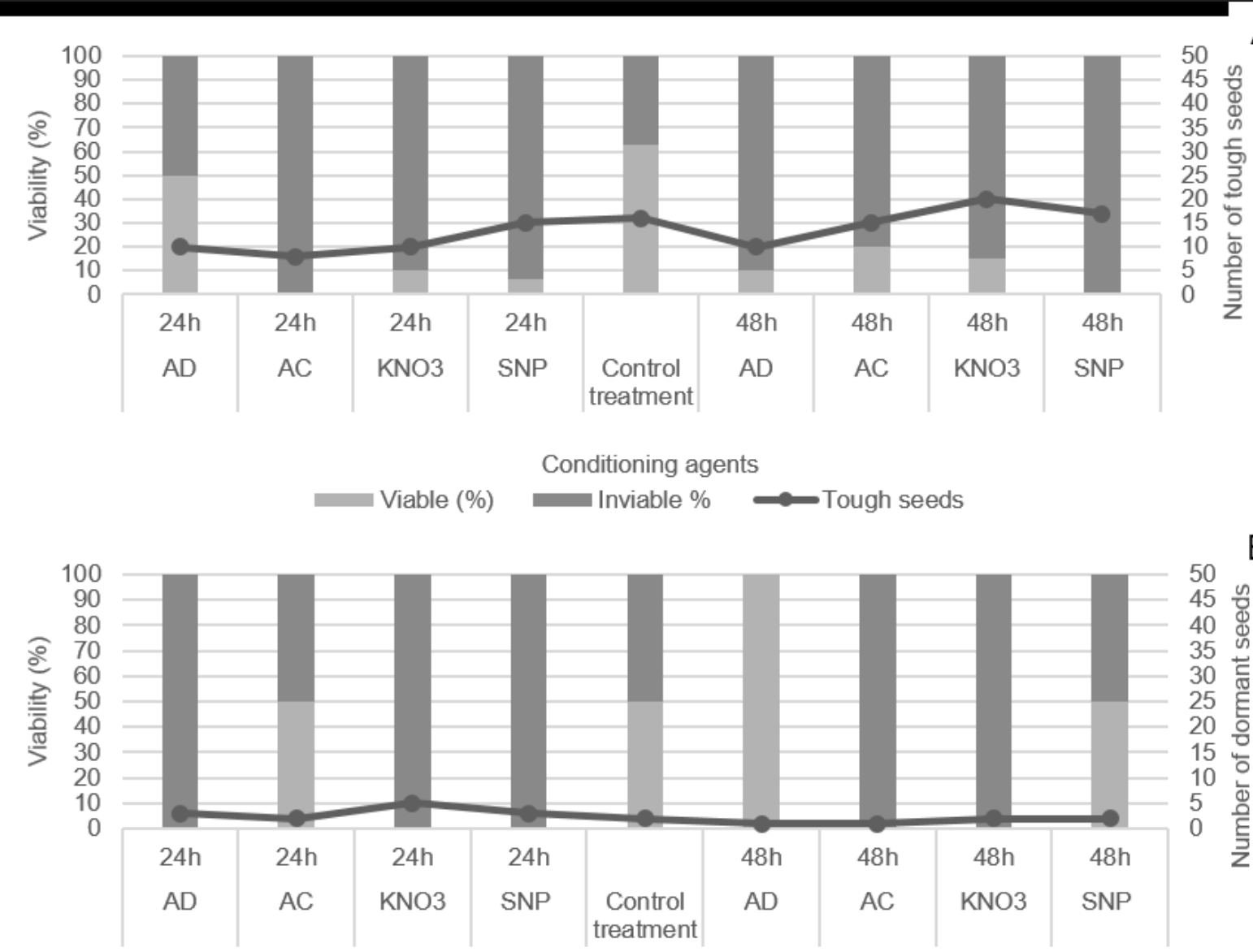
Fernandes, A. C.; Faria, J. C. T.; Faria, J. M. R.; Pires, R. M. O.; Carvalho, E. R.; Santos, H. O. | 824

Yogeesha et al. (2005) stored annatto seeds with water content between 58$65 \%$ aiming to maintain high germination under this condition. However, the storage period consisted of only 22 days because damages inflicted upon the seeds during processing resulted in an early fungal infestation. After storing the fruits at $4^{\circ} \mathrm{C}$ for 40 days, there was no decrease in germination percentage. After this period, however, the seeds lost viability due to fungal growth. Even under these conditions, the authors classified the annatto seeds as orthodox.

Figure 4 - Results from the tetrazolium test for tough (A) and dormant seeds (B) from the stored lot (Lot 2) that remained after the germination test: conditioned in deionized water (AD) for 24 and 48h, conditioned in cathodic water (AC) for 24 and 48h, conditioned in potassium nitrate $\left(\mathrm{KNO}_{3}\right)$ for 24 and $48 \mathrm{~h}$ and conditioned in sodium nitroprusside (SNP) for 24 and $48 \mathrm{~h}$
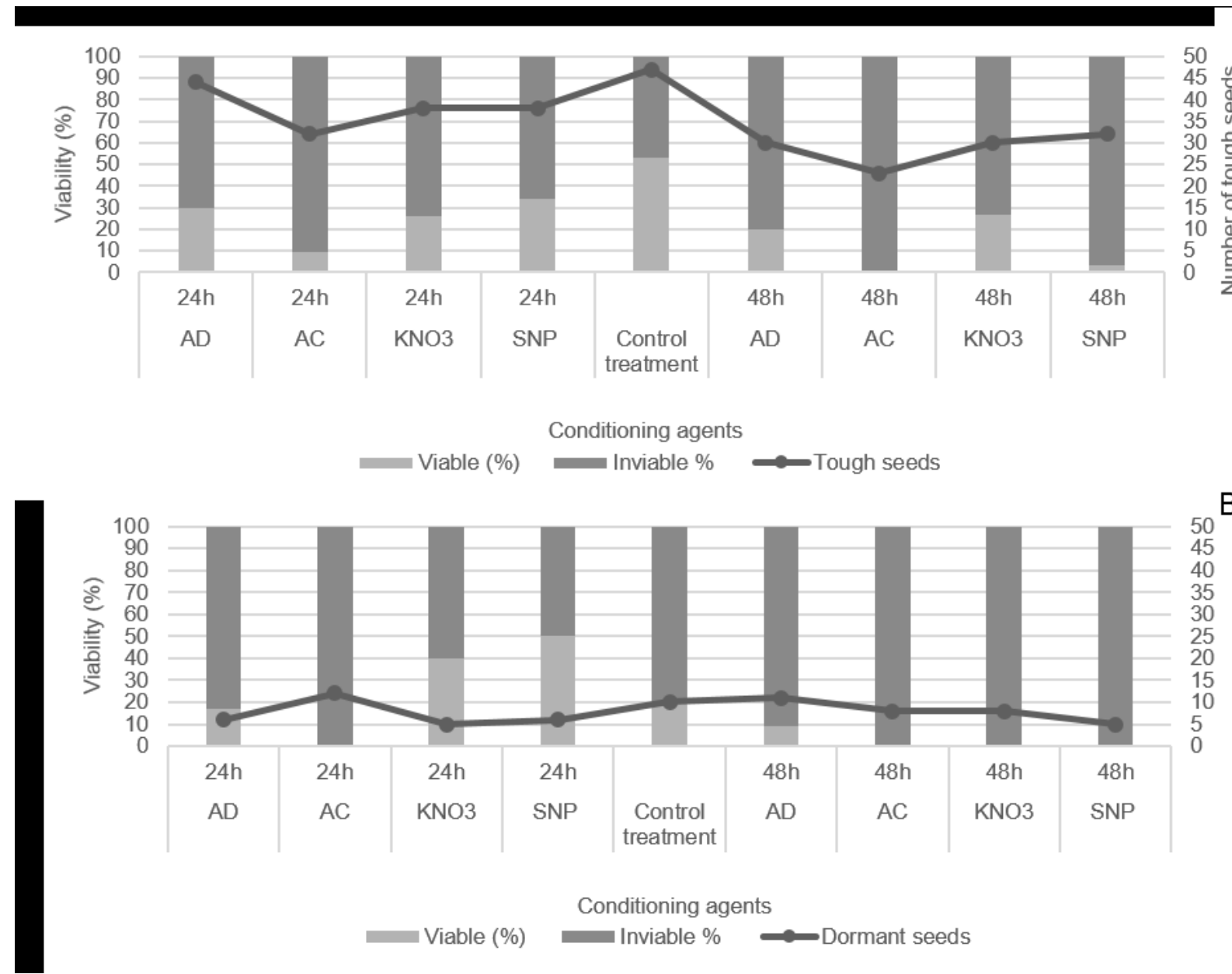

Source: Authors (2020) 
Tolerant seeds support naturally dry conditions at the end of maturation. They are generally dispersed with low metabolism and water content (as low as 7\%) and may be stored for long periods (WYSE; DICKIE, 2017). Intermediate seeds, on the other hand, show moderate tolerance to desiccation and storage (ELLIS et al., 1990).

Despite their low percentage of germination (36\%) and water content (8\%), lot 2 seeds germinated even after 10 years of storage in a cold dry chamber $(40 \%$ RU and $10^{\circ} \mathrm{C}$ ), characterizing this species as non-tolerant (orthodox seeds). Here, as in other studies, germination was influenced by a water content decrease. However, unlike other studies that reported seed dormancy as a cause of germination decrease, this was not observed here. More studies are needed to guide the classification of annatto seeds in terms of storability and dormancy.

\section{CONCLUSION}

Here, we observed annatto seed germination without any type of dormancybreak pretreatment, even in seeds stored for over 10 years with a water content of $8 \%$. This characterizes this species as non-dormant. The germination and viability of Bixa orellana are influenced by seed water content decrease. The conditioning agents used here were not efficient to increase annatto seed germination.

\section{REFERENCES}

AMARAL, L.I.V.; PEREIRA, M.F.D.A.; CORTELAZZO, A.L. Germinação de sementes em desenvolvimento de Bixa orellana. Revista Brasileira de Fisiologia Vegetal, Brasília, v. 12, n. 3, p. 273-285, oct. 2000.

ASSOCIATION OS OFFICIAL SEED ANALYSTIS - AOSA. Seed vigour testing handbook. East Lansing: AOSA, 1983. 93p.

ARAUJO NETO, A.C.; SANTOS, O.O.; FERREIRA, D.M; NUNES, R.T.C; PÚBLIO, A.P.P.B; AMARAL, C.L.F. Germination and vigor of Bixa orellana L. seeds pre-soaked in a plant biostimulant. Floresta, Curitiba, v. 48, n. 3, p 293-302, jul/sep. 2018.

ATAÍDE, G.M.; BORGES, E.E.L.; FLORES, A.V.; CASTRO, R.V.O. Óxido nítrico na germinação de sementes de baixo vigor de Dalbergia nigra. Revista de Ciências Agrárias, [s.l], v. 38, n. 3, p. 438-444, apr. 2015. 
BASKIN, C.C.; BASKIN, J.M. Seeds: ecology, biogeography, and evolution of dormancy and germination. San Diego, USA: Elsevier, 2014.

BERJAK, P.; SERSHEN, B.V; PAMMENTER, N.W. Cathodic amelioration of the adverse effects of oxidative stress accompanying procedures necessary for cryopreservation of embryonic axes of recalcitrant-seeded species. Seed Science Research, [s.I], v. 21, n. 3, p. 187-203, may. 2011.

BEWLEY, J.D.; BRADFORD, K.J.; HILHORST, H.W.M.; NONOGAKI, H. Seeds: Physiology of Development, Germination and Dormancy. USA: Springer, 2013.

BRAZIL. Regras para análise de sementes. Brasilia: Ministério da Agricultura, Pecuária e Abastecimento. Secretaria de Defesa Agropecuária, 2009.

CARMO, A.L.M.; MAZARATTO, E.J.; ECKSTEIN, B.; SANTOS, Á.F. Associação de fungos com sementes de espécies florestais nativas. Summa Phytopathologica, Botucatu, v. 43, n. 3, p. 246-247, apr. 2017.

CASTELLO, M.C.; SHARAN, M.; MADHURI, S. In vitro culture studies of Bixa orellana L.: IV-in vitro and in vivo trials for breaking the dormancy of seeds of Bixa orellana. European Journal of Experimental Biology, [s.I], v. 2, n. 1, p. 174-179, jan. 2012.

COSTA, R.N.; SANTOS, W.J.; LIMA, J.L.; ACCHILE, S; SANTOS NETO, A.L.; SILVA, J.V. Avaliação de diferentes métodos pré-germinativos para três espécies arbóreas da família Fabaceae em diferentes ambientes. Scientific Electronic Archives, [s.I], v. 11, n. 1, p. 35-43, feb. 2018.

DAS, A.; MANDAL, S.; NAG, S. Seed germination of annatto (Bixa orellana L.) - A review. International Journal of Recent Scientific Research, [s.I], v. 9, n. 4, p. 26257-26260, apr. 2018.

DELOUCHE, J.C.; BASKIN, C.C. Accelerated aging techniques for predicting the relative storability of seeds lots. Seed Science and Technology. v.1, n.2, p.427-452. 1973.

ELLIS, R.H.; HONG, T.D.; ROBERTS, E.H. An intermediate category of seed storage behaviour?: I. Coffee. Journal of Experimental Botany, [s.I], v. 41, n. 9, p. 1167-1174, 1990.

FERREIRA, R.L.; NOVEMBRE, A.D.L.C. Teste de germinação de sementes de urucum (Bixa Orellana L.). Multi-Science Journal, [s.I], v. 1, n. 3, p. 46-52, may. 2015.

GOLDBACH, H. Germination and storage of Bixa orellana seeds. Seed Science and Technology, [s.I], v. 7, p. 399-402, jul. 1979.

GOMES, J.A.O.; TEIXEIRA, D.A.; BONFIM, F.P.G.; PARREIRAS, N.S. Métodos para quebra de dormência em sementes de Bixa orellana L. Revista Mirante, Anápolis, v. 9, n. 1, p. 1-10, jun. 2016.

JOSEPH, N.; SIRIL, E.A.; NAIR, G.M. Imbibition duration, seed treatment, seed mass and population linfluence germination of annatto (Bixa orellana L.) seeds. Seed Technology, [s.I], v. 32, n. 1, p. 37-45, apr. 2010.

KISSMANN,C.; SCALON,S.P.Q.; TEODÓSIO, T.K.C. Condicionamento das sementes e sombreamento na emergência e no crescimento de plantas de Bixa orellana L. Revista de Ciências Agrárias, [s.I], v. 36, n. 2, p. 48-56, nov. 2013. 
LOPES, J.C.; LIMA, R.V.; MACEDO, C.M.P. Germinação evigor de sementes de urucu. Horticultura Brasileira, [s.I], v. 26, n. 1, p. 19-25, jan/mar. 2008.

MAGUIRE, J.D. Speed of germination-aid in selection and evaluation for seedling emergence and vigor. Crop Science, [s.I], v. 53, n. 2, p. 176-177, 1962.

MARCOS-FILHO, J. Fisiologia de sementes de plantas cultivadas. Londrina: ABRATES, 2015.

PEREIRA, B.L.C.; BORGES, E.E.L.E; OLIVEIRA, A.C.; LEITE, H.G.; GONÇALVES, J.F.C. Influência do óxido nítrico na germinação de sementes de Plathymenia reticulata Benth com baixo vigor. Scientia Florestalis, Piracicaba, v. 38, n. 88, p. 629-636, dez. 2010.

PEREIRA, W.V.S.; FARIA, J.M.R.; TONETTI, O.A.O.; SILVA, E.A.A. Desiccation tolerance of Tapirira obtusa seeds collected from different environments. Revista Brasileira de Sementes, [s.I], v. 34, n. 3, p. 388-396, 2012.

PICOLOTTO, D.R.N.; THEODORO, J.V.C.; DIAS, A.R.; THEODORO, G.F.; ALVES, C.Z. Germinação de sementes de urucum em função de métodos de superação de dormência e temperaturas. Pesquisa Agropecuária Tropical, Goiânia, v. 43, n. 3, p. 232-238, jul/set. 2013.

POORNIMA, S.; AMBIKA, S.R. Germination studies in an important natural food dye yielding plant Bixa orellana L. International Journal of Innovations in Bio-sciences, [s.I], v. 2, n. 1, p. 48-50, jan. 2012.

R CORE TEAM. A language and environment for statistical computing: reference index version 3.6.1., 2019.

SANTOS, M.C.A.; AROUCHA, E.M.M.; SOUZA, M.S.; SILVA, R.F.; SOUZA, P.A. Condicionamento osmótico de sementes. Revista Caatinga, Mossoró, v. 21, n. 2, p. 1-6, apr/jun. 2008.

SOUZA, M.C.S.; PIÑA-RODRIGUES, F.C.M.; CASAGRANDE, J.C.; SILVA, S.F.; SCORIZA, R.N. Funcionalidade ecológica de sistemas agroflorestais biodiversos: Uso da serapilheira como indicador da recuperação de áreas de preservação permanente. Floresta, Curitiba, v. 46, n. 1, p. 75-82, nov. 2016.

VILAR, D.D.A.; VILAR, M.S.D.A.; MOURA, T.F.A.L.; RAFFIN, F.N.; OLIVEIRA, M.R.; FRANCO, C. F.O.; ATHAYDE FILHO, P.F.; DINIZ, M.F.F.M.; BARBOSA FILHO, J. M. Traditional uses, chemical constituents, and biological activities of Bixa Orellana L.: A review. Scientific World Journal, [s.l], v. 2014, p. 1-11, jun. 2014.

WYSE, S.V.; DICKIE, J.B. Predicting the global incidence of seed desiccation sensitivity. Journal of Ecology, [s.I], v. 105, n. 4, p. 1082-1093, dec. 2017.

YOGEESHA, H.S.; SHIVANANDA, T.N.; BHANUPRAKASH, K. Effect of seed maturity, seed moisture and various pre-treatments on seed germination of annatto (Bixa orellana L.). Seed Science and Technology, [s.I], v. 33, n. 1, p. 97-104, feb. 2005. 


\section{Authorship Contribution}

\section{1 - Alana Chocorosqui Fernandes}

Forestry Engineer, Dr., Professor

https://orcid.org/0000-0003-3090-293X•alana.fernandes@ifac.edu.br

Contribution: Writing - original draft, Project administration, Investigation, Writing review \& editing, Visualization

\section{2 - Julio Cezar Tannure Faria}

Forestry Engineer, Dr.

https://orcid.org/0000-0001-7081-3726•jc.tannure@gmail.com

Contribution: Data curation, Visualization

\section{3 - José Marcio Rocha Faria}

Forestry Engineer, Dr., Professor

https://orcid.org/0000-0003-0365-2787•jmfaria@ufla.br

Contribution: Writing - review \& editing, Supervision

\section{4 - Raquel Maria de Oliveira Pires}

Agronomist, Dr., Professor

https://orcid.org/0000-0003-1369-4323•raquelmopires@ufla.br

Contribution: Funding acquisition, Methodology, Supervision

\section{5 - Everson Reis Carvalho}

Agronomist, Dr., Professor

https://orcid.org/0000-0003-4925-4100•eversoncarvalho@ufla.br

Contribution: Funding acquisition, Supervision

\section{6 - Heloisa Oliveira dos Santos}

Forestry Engineer, Agronomist, Dr., Professor

https://orcid.org/0000-0003-1384-4969•heloisa.osantos@ufla.br

Contribution: Funding acquisition, Project administration, Methodology, Supervision 


\section{How to quote this article}

Fernandes, A. C.; Faria, J. C. T.; Faria, J. M. R.; Pires, R. M. O.; Carvalho, E. R.; Santos, H. O. Use of different conditioning agents and quality evaluation of two lots of annatto (Bixa orellana) seeds. Ciência Florestal, Santa Maria, v. 31, n. 2, p. 808-829, 2021. DOI 10.5902/1980509844156. Available from: https://doi.org/10.5902/1980509844156. Accessed: xx abbreviated-month 2021. 